\title{
Evaluasi penggunaan obat dan identifikasi drug related problem (DRP) pada pasien pneumonia di ruang rawat inap rumah sakit umum pusat Fatmawati Jakarta (periode Desember 2014 - Februari 2015)
}

\author{
Diar Gustianti Istita ${ }^{*}$, Dian Ratih Laksmitawati², Magdalena Niken³ \\ ${ }^{1}$ Puskesmas Labuhan Ratu Bandar Lampung. *Email: diaristita25@gmail.com \\ 2Universitas Pancasila. Email: dianratih.ffup@gmail.com \\ ${ }^{3}$ Rumah Sakit Umum Pusat Fatmawati Jakarta. Email: lenasanjaya1@gmail.com
}

\section{Abstract \\ Evaluation of drug use and drug related problem identification among patients with pneumonia}

Background : Pneumonia is still a public health problem cause in mortality of due to this disease in various countries. Based on the burden of the Global Disease Study in 2010 which reported 90\% of pneumonia cases occurring at the age of 65 years and pneumonia became the greatest need after ischemic heart disease, stroke and chronic obstructive pulmonary disease (COPD) in European countries. The high incidence of pneumonia needs treatment therapy as accurate and rationally, to ensure that the drugs used are appropriate, safe, and efficient.

Purpose: To evaluation of drug use and drug related problem identification among patients with pneumonia at Fatmawati General Hospital, December 2014-February 2015

Method: This study uses a cross sectional study design by observing samples and analyzing the data descriptively. The flow of data collection is prospective among patients with pneumonia

Results: 25 cases of DRP occurrences. From 30 patients found 18 patients who experienced DRP events with a total of 25 cases, in this case 1 patient could experience more than 1 case of DRP events. In this study the most cases occurred in the domain (P1.2), namely the effect of the drug is not optimal as many as 20 cases (80\%) with causes of DRP associated with drug dose selection (C.3) include (C3.1) less than a number of doses $\backslash / 2$ cases $(8 \%),(C 3.4)$ the frequency of administration was 15 cases $(60 \%)$, then (C3.2) overdose of 3 cases $(12 \%)$.

Cases that often arise are in the category of dose selection caused by (C3.4) the frequency of administration is lacking. There were 15 patients who received ranitidine injection at a dose of $50 \mathrm{mg}$ every 12 hours per day, whereas the dose listed in the Drugs Information of Handbook library was $50 \mathrm{mg}$ every 6-8 hours per day. The doctor's consideration in giving ranitidine dose $2 \times 50 \mathrm{mg} /$ day is as a prophylactic therapy for the use of several drugs that can increase stomach acid production such as corticosteroids, NSAIDs, NSAID drugs combined with aspirin, and anticoagulant drugs.

Conclusion : Knowing that the 5 most therapeutic drug classes used in Fatmawati General Hospital are 30 patients $(100 \%)$ antibiotics, 30 patients (100\%) bronchodilators, 28 patients $(93 \%)$ anti-peptic ulcer, anti-hypertension. 23 patients $(77 \%)$ and mucolytic 22 patients $(77 \%)$. The results showed that there were 18 Drug Related Problems (DRP) patients experiencing DRP events out of 25 total cases, the majority of DRP events were in the domain.

\section{Keywords: Evaluation; Drug use; Drug Related Problem; Identification; Patients; Pneumonia}

Pendahuluan : Pneumonia masih menjadi masalah kesehatan masyarakat menyebabkan kematian akibat penyakit ini di berbagai negara. Berdasarkan Global Burden of Disease Study pada 2010 yang melaporkan 90\% kasus pneumonia terjadi pada usia 65 tahun dan pneumonia menjadi masalah terbesar setelah penyakit jantung iskemik, stroke dan penyakit paru obstruktif kronik (PPOK) di negara-negara Eropa. Tingginya insiden pneumonia dapat menimbulkan risiko kematian, sehingga terapi pengobatan harus dilakukan secara rasional, untuk memastikan bahwa obat yang digunakan sesuai, aman, dan efisien.

Tujuan : Untuk mengevaluasi penggunaan obat dan mengetahui ada tidaknya permasalahan terkait obat (DRPs) pada pasien Pneumonia. 
Evaluasi penggunaan obat dan identifikasi drug related problem (DRP) pada pasien pneumonia di ruang rawat inap rumah sakit umum pusat Fatmawati Jakarta (periode Desember 2014 - Februari 2015)

Metode: Menggunakan desain cross sectional dengan mengamati sampel dan menganalisis data secara deskriptif. Pengumpulan data prospektif pada pasien dengan pneumonia di bangsal rumah sakit.

Hasil: Diperoleh 25 kasus kejadian DRP. Dari 30 pasien ditemukan 18 pasien yang mengalami kejadian DRP dengan total kasus sejumlah 25, dalam hal ini 1 pasien dapat mengalami lebih dari 1 kasus kejadian DRP. Dalam penelitian ini kasus terbanyak terjadi pada domain (P1.2) yaitu efek obat tidak optimal sebanyak 20 kasus (80\%) dengan penyebab DRP yang berkaitan dengan pemilihan dosis obat (C.3) meliputi (C3.1) dosis kurang sejumVlah 2 kasus (8\%), (C3.4) frekuensi pemberian kurang sejumlah 15 kasus (60\%), kemudian (C3.2) dosis berlebih sebanyak 3 kasus (12\%). Kasus yang sering muncul yaitu pada kategori pemilihan dosis yang disebabkan (C3.4) frekuensi pemberian kurang. Terdapat 15 pasien yang mendapatkan ranitidin injeksi dengan dosis $50 \mathrm{mg}$ tiap 12 jam perhari, sedangkan dosis yang tercantum dalam pustaka Drugs Information of Handbooks yaitu $50 \mathrm{mg}$ tiap 6-8 jam perhari. Pertimbangan dokter dalam memberikan dosis ranitidine $2 \times 50 \mathrm{mg} /$ hari yaitu sebagai terapi profilaksis terhadap penggunaan beberapa obat yang dapat meningkatkan produksi asam lambung seperti kortikosteroid, NSAID, Obat NSAID yang dikombinasi dengan aspirin, dan obat antikoagulan.

Simpulan: Diketahui bahwa 5 kelas terapi obat terbanyak yang digunakan di RSUP Fatmawati adalah antibiotik sebanyak 30 pasien (100\%), bronkodilator sebanyak 30 pasien (100\%), anti tukak lambung sebanyak 28 pasien (93\%), anti hipertensi sebanyak 23 pasien $(77 \%)$ dan mukolitik sebanyak 22 pasien $(77 \%)$. Hasil penelitian menunjukkan bahwa Drug Related Problem (DRP) terdapat 18 pasien mengalami kejadian DRP dari 25 jumlah total kasus, mayoritas kejadian DRP terdapat pada domain

\section{Kata kunci: Evaluasi; Penggunaan obat; Identifikasi Drug Related Problem (DRP); Pasien; Pneumonia}

\section{PENDAHULUAN}

Infeksi saluran pernafasan merupakan masalah kesehatan masyarakat yang serius di berbagai negara di dunia. Salah satu infeksi umum yang menyerang saluran pernafasan bagian bawah adalah pneumonia. Pneumonia adalah suatu proses inflamasi yang melibatkan alveoli dan bronkiolus, disebabkan oleh bakteri, virus atau parasit (Sudoyo, Setiyohadi, Alwi, Simadibrata, \& Setiati, 2010).

Pneumonia sering ditemukan pada anak-anak, orang dewasa, dan pada kelompok usia lanjut. Penyakit ini dapat menyebabkan kematian jika tidak segera diobati (Dipiro, Talbert, Yee, Matzke, \& Wells, \& Posey, 2015). Pada orang dewasa, pneumonia bisa menjadi infeksi serius yang dapat berkembang menjadi sepsis dan berpotensi mengancam jiwa. Pneumonia masih merupakan problem kesehatan masyarakat karena tingginya angka kematian disebabkan penyakit tersebut diberbagai negara termasuk di Indonesia (Kaparang, 2014) Berdasarkan Global Burden of Disease Study tahun
2010 melaporkan bahwa sekitar 90\% kasus pneumonia terjadi pada usia diatas 65 tahun dan penyakit pneumonia menjadi urutan empat terbesar setelah penyakit iskemik jantung, stroke dan penyakit paru obstruktif kronik (PPOK) di negara eropa (Lozano, Naghavi, Foreman, Lim, Shibuya, Aboyans, \& AlMazroa, 2012)

Di Amerika Serikat, pada tahun 2011 pneumonia termasuk ke dalam delapan penyakit paling banyak menyebabkan kematian, yaitu sebanyak 257.000 terjadi pada orang dewasa dan 621.000 terjadi pada usia lanjut. Angka kematian pneumonia untuk pasien rawat jalan masih rendah yaitu 1-5\% sedangkan angka kematian pasien pneumonia rawat inap yaitu $12 \%$ (American Thoracic Society, \& Infectious Diseases Society of America, 2005).

Di rumah sakit di Kanada insiden pneumonia sebanyak 1,29 per 1000 penduduk pada kelompok usia 18-39 tahun menjadi 1,91 per 1000 penduduk pada usia 40-54 tahun dan meningkat menjadi 13,21 per 1000 penduduk pada usia di atas 55 tahun. Sedangkan, di Indonesia kasus pneumonia

Diar Gustianti lstita"* Puskesmas Labuhan Ratu Bandar Lampung, *Email: diaristita25@gmail.com

Dian Ratih Laksmitawati ${ }^{2}$ Universitas Pancasila. Email: dianratih.ffup@gmail.com

Magdalena Niken ${ }^{3}$ Rumah Sakit Umum Pusat Fatmawati Jakarta. *Email: lenasanjayal@gmail.com 
Evaluasi penggunaan obat dan identifikasi drug related problem (DRP) pada pasien pneumonia di ruang rawat inap rumah sakit umum pusat Fatmawati Jakarta (periode Desember 2014 - Februari 2015)

mencapai 22.000 jiwa menduduki peringkat ke delapan sedunia (Dipiro, Talbert, Yee, Matzke, \& Wells, \& Posey, 2015).

Berdasarkan Hasil Riset Kesehatan Dasar (RISKESDAS) tahun 2013, prevalensi kejadian pneumonia di Indonesia mencapai $1,8 \%$ dan $4,5 \%$, dan kasus pneumonia terjadi di lima provinsi di Indonesia antara lain Nusa Tenggara Timur $(4,6 \%$ dan $10,3 \%$, Papua (2,8 dan $8,2 \%$ ), Sulawesi Tengah (2,3\% dan $5,7 \%)$, Sulawesi Barat $(3,1 \%$ dan $6,1 \%)$, Sulawesi Selatan (2,4\% dan 4,8\%) (Badan Penelitian dan Pengembangan Kesehatan Kementerian Kesehatan Republik Indonesia, 2013). Sebelumnya telah dilakukan berbagai penelitian mengenai pneumonia di beberapa rumah sakit di Indonesia seprti Rumah Sakit Pondok Puri Indah mencapai 161 kasus pada tahun 2014 (Munarsih, Natadidjaja, \& Syamsudin, 2018). Kejadian pneumonia di Rumkital Dr. Mintohardjo pada tahun 2014 sebanyak 36 kasus dan sebanyak 57 kasus terjadi pada tahun 2015 (Purwanggana, Nissa, \& Fauziyah, 2016).

Angka mortalitas pasien pneumonia di RSUD Cengkareng pada tahun 2013-2014 sebanyak 16 pasien (16,5\%) dengan penyebab kematian terbanyak yaitu gagal napas sebanyak 9 pasien $(9,3 \%)$ (Ade, 2018). Tingginya angka kejadian pneumonia tersebut dapat menimbulkan risiko terjadinya kematian, maka penanganan terapi pengobatan harus dilakukan secara rasional, untuk menjamin agar obat-obat yang digunakan tepat, aman, dan efisien. Kebanyakan pasien pneumonia yang masuk ke ruang perawatan dalam kondisi kritis seperti kegagalan pernapasan akut, gagal jantung, gangguan keseimbangan asam basa, penurunan kesadaran pasca operasi, penyakit paru yang disertai komplikasi penyakit akut berat, dan lain sebagainya. Dari komplikasi penyakit yang terjadi, pasien akan membutuhkan obat yang lebih banyak dari pada pasien tanpa adanya komplikasi. Banyaknya jumlah obat yang diterima pasien pneumonia selama menjalani perawatan di RSUP Fatmawati rata-rata sebesar 8-10 item obat per-pasien, karena terapi obat yang diberikan dokter tidak hanya untuk mengobati pneumonia saja tetapi juga mengobati penyakit penyerta yang diderita pasien, hal ini dapat menyebabkan terjadinya polifarmasi dan bila penggunaan obat di konsumsi secara bersamaan dapat menimbulkan terjadinya Drug Related Problem (DRP) berupa interaksi obat baik potensial maupun aktual (Syukriati, 2016).

Sebagai salah satu contoh frekuensi kejadian DRP pada pasien pneumonia yang diteliti di RSUD Pusat H. Adam Malik Medan pada tahun 2010, kategori indikasi tanpa obat sebesar $3,33 \%$, obat tanpa indikasi sebesar $10 \%$, dosis salah sebesar $6,67 \%$ dan interaksi obat obat sebesar 53,33\%, sedangkan tahun 2011 kejadian DRP kategori obat tanpa indikasi sebesar $9,52 \%$, dosis salah sebesar $14,29 \%$, dan interaksi obat sebesar $66,67 \%$ (Astiti, Mukaddas, \& Illah, 2017).

Rumah Sakit Fatmawati merupakan rumah sakit rujukan pemerintah tipe A pendidikan dan sebagai rumah sakit rujukan nasional yang memberikan pelayanan kesehatan terhadap berbagai jenis penyakit dan memiliki fasilitas pelayanan rawat inap maupun rawat jalan. Menurut data medical record, penyakit pneumonia merupakan penyakit sepuluh terbanyak pada tahun 2013. Berdasarkan pernyataan diatas perlunya penelitian lebih lanjut untuk mengevaluasi penggunaan obat dan mengidentifikasi DRP yang terjadi. Evaluasi penggunaan obat ini dilakukan agar dapat memastikan terapi suatu obat dapat aman, tepat, dan efektif dalam penggunaanya. Dalam penelitian ini penggunaan obat akan dievaluasi menggunakan standar pengobatan yang digunakan dan sedangkan masalah terkait obat akan diidentifikasi menggunakan formulir Pharmaceutical Care Network Europe (PCNE) versi 6.2 sebagai instrumen untuk mendokumentasikan masalah terkait obat. Evaluasi Drug Related Problem dibutuhkan untuk

Diar Gustianti lstita"* Puskesmas Labuhan Ratu Bandar Lampung, *Email: diaristita25@gmail.com

Dian Ratih Laksmitawati ${ }^{2}$ Universitas Pancasila. Email: dianratih.ffup@gmail.com

Magdalena Niken ${ }^{3}$ Rumah Sakit Umum Pusat Fatmawati Jakarta. *Email: lenasanjayal@gmail.com 
Evaluasi penggunaan obat dan identifikasi drug related problem (DRP) pada pasien pneumonia di ruang rawat inap rumah sakit umum pusat Fatmawati Jakarta (periode Desember 2014 - Februari 2015)

meningkatkan efektivitas terapi terutama pada penyakit pneumonia yang disertai adanya komplikasi penyakit lain.

Penelitian ini diharapkan dapat membantu meningkatkan pelayanan rumah sakit pusat fatmawati agar tercapai suatu keberhasilan terapi serta memberikan informasi kepada paramedis dan untuk melaksanakan terapi pengobatan pasien pneumonia yang sesuai dengan tatalaksana pedoman pengobatan pneumonia yang digunakan di RSUP Fatmawati Jakarta.

\section{METODE PENELITIAN}

Penelitian cross sectional dengan mengobservasi sampel dan data di analisa secara deskriptif dan alur pengambilan data bersifat prospektif pada pasien pneumonia di ruang rawat inap Rumah Sakit Umum Pusat Fatmawati pada periode (Desember 2014Februari 2015). Pengumpulan data diperoleh dari data rekam medik, selanjutnya dilakukan pengorganisasian data. Data terdiri dari 3 macam yaitu data demografi, data penggunaan obat dan data permasalahan terkait obat yang diklasifikasikan menurut metode PCNE versi 6.2. Kemudian data yang diperoleh di analisa secara deskriptif. Instrumen yang digunakan; formulir pemantauan terapi obat pasien.(Lampiran 20), formulir PCNE V6.2. (Lampiran 17) dan pedoman penatalaksanaan pneumonia (Perhimpunan Dokter Paru Indonesia, 2003; American Thoracic Society, \& Infectious Diseases Society of America, 2005; Mandell, Wunderink, Anzueto, Bartlett, Campbell, Dean, \& Torres, 2007).

Data penelitian ini diperoleh dari rekam medis, data laboratorium, dan catatan penggunaan obat pasien. Data-data tersebut dikumpulkan dalam formulir profil pengobatan pasien yang telah dirancang oleh peneliti sebagai berikut : (1) Mencatat data identitas pasien (nama, usia, jenis kelamin, berat badan, tanggal masuk dan keluar pasien), diagnosa, riwayat penyakit pasien, riwayat penyakit keluarga, riwayat alergi, riwayat penggunaan obat sebelumnya; (2) Mencatat hasil pemeriksaan fisik meliputi kesadaran, nadi, suhu tubuh, nafas dan tekanan darah; (3) Mencatat hasil pemeriksaan laboratorium berdasarkan data rekam medis; (4) Mencatat data penggunaan obat pasien meliputi ; nama obat, indikasi, dosis, frekuensi pemberian, rute pemberian, tanggal, dan aturan penggunaan obat; (5) Data-data yang sudah dicatat ke dalam formulir profil pengobatan pasien, kemudian dilakukan penilaian terhadap masalah terkait obat (DRP) dengan menggunakan formulir PCNE V.6.2; (6) DRP yang sudah diidentifikasi dengan PCNE kemudian didiskusikan dengan Apoteker di RSUP Fatmawati untuk menentukan rekomendasi yang akan diberikan ke staf medis atau perawat dengan menggunakan form rekomendasi farmasi klinis; (7) Hasil rekomendasi kemudian dievaluasi berdasarkan formulir PCNE V6.2 dengan kategori 01 sampai 04.

\section{PEMBAHASAN}

Pasien penderita pneumonia rawat inap di RSUP Fatmawati periode Desember 2014 - Februari 2015 menunjukkan bahwa dari 51 pasien yang memenuhi kriteria inklusi dan eksklusi adalah 30 pasien, 21 pasien yang tidak termasuk kriteria dalam penelitian ini yaitu 3 pasien meninggal, 15 pasien penderita gangguan ginjal kronik, dan 3 pasien hemodialisa., di karenakan terdapat banyak penyesuaian dosis pada pasien yang mengalami penyakit gangguan ginjal sehingga dapat mempengaruhi hasil dalam menganalisa penelitian ini.

Diar Gustianti lstita"* Puskesmas Labuhan Ratu Bandar Lampung, *Email: diaristita25@gmail.com

Dian Ratih Laksmitawati ${ }^{2}$ Universitas Pancasila. Email: dianratih.ffup@gmail.com

Magdalena Niken ${ }^{3}$ Rumah Sakit Umum Pusat Fatmawati Jakarta. *Email: lenasanjayal@gmail.com 
Evaluasi penggunaan obat dan identifikasi drug related problem (DRP) pada pasien pneumonia di ruang rawat inap rumah sakit umum pusat Fatmawati Jakarta (periode Desember 2014 - Februari 2015)

\section{Tabel.1 Distribusi Frekuensi Pasien N=30}

\begin{tabular}{lcc}
\hline Variabel & Frekuensi (f) & Persentase (\%) \\
\hline Jenis Kelamin & & \\
Pria & 19 & 63 \\
Wanita & 11 & 37 \\
& & \\
Kelompok usia & - & - \\
18-25 tahun & 4 & 13,3 \\
26-45 tahun & 10 & 33 \\
46-65 tahun & 16 & 53,3 \\
$>$ 65 tahun & & \\
& & - \\
Pendidikan & - & 47 \\
Tidak Sekolah & 14 & 10 \\
Tamat SMP & 3 & 10 \\
Tamat SMA & 3 & 33 \\
Tamat Akademik & 10 & \\
ITamat Universitas & & 3,3 \\
Pekerjaan & 1 & 10 \\
PNS & 3 & 30 \\
Pegawai Swasta & 9 & 37 \\
Ibu Rumah Tangga & 11 & 20 \\
Pensiunan & 6 & \\
Lain-Lain & & 100 \\
Jenis Penyakit & & \\
Penyerta & 30 & \\
\hline
\end{tabular}

Jumlah pasien laki-laki 19 pasien (63\%) lebih banyak dibandingkan perempuan dan hasil yang sama seperti penelitian sebelumnya bahwa penderita saluran pernafasan seperti pneumonia lebih sering ditemukan pada pria dibandingkan wanita. Persentase banyaknya laki-laki yang menderita pneumonia juga berkaitan kerentanan laki-laki terhadap kebiasaan buruk yang dilakukan seperti mengkonsumsi rokok atau memiliki riwayat sebagai perokok yang merupakan salah satu faktor penyebab terjadinya pneumonia, karena asap rokok memiliki banyak zat kimia yang dapat memicu terjadinya infeksi saluran pernapasan, merokok dapat mempengaruhi transpor mukosiliar, pertahanan humoral dan seluler dan fungsi sel epitel, serta meningkatkan perlekatan Streptococcus pneumoniae dan Haemophylus influenzae (Nugroho, Utami, \& Astuti, 2011).

Berdasarkan rentang usia, yang paling banyak adalah kelompok usia lebih dari 65 tahun yaitu 17 (57\%). Hasil penelitian yang sama dengan penelitian sebelumnya di Rumah Sakit Cipto Mangunkusumo pada tahun 2000, dimana usia $>65$ tahun lebih banyak menderita pneumonia mencapai $54,8 \%$ dengan tingkat mortalitas sebesar $32,5 \%$. Hasil penelitian ini berbeda dengan penelitian yang dilakukan di Rumkital Dr. Mintohardjo dimana dalam penelitiannya usia terbanyak penderita pneumonia rata-rata 56-65 tahun sebesar 11 pasien (33,3\%) (Purwanggana, Nissa, \& Fauziyah, 2016). Dari data tersebut menunjukkan penyakit pneumonia dapat terjadi seiring bertambahnya usia, hal ini disebabkan karena semakin tua umur pasien, maka ketahanan tubuh terhadap penyakit semakin rendah dan fungsi

Diar Gustianti lstita ${ }^{1 *}$ Puskesmas Labuhan Ratu Bandar Lampung, *Email: diaristita25@gmail.com

Dian Ratih Laksmitawati ${ }^{2}$ Universitas Pancasila. Email: dianratih.ffup@gmail.com

Magdalena Niken ${ }^{3}$ Rumah Sakit Umum Pusat Fatmawati Jakarta. *Email: lenasanjayal@gmail.com 
Evaluasi penggunaan obat dan identifikasi drug related problem (DRP) pada pasien pneumonia di ruang rawat inap rumah sakit umum pusat Fatmawati Jakarta (periode Desember 2014 - Februari 2015)

paru dalam tubuh akan mengalami penurunan sehingga mudah terserang virus dan bakteri (Faisal, Burhan, Aniwidyaningsih, \& Kekalih, 2014).

Berdasarkan tingkat pendidikan terbanyak adalah tamatan SD yaitu 14 pasien sebesar (47\%), hal ini berbeda dengan penelitian sebelumnya, bahwa tingkat pendidikan terbanyak pasien pneumonia adalah tingkat SMA diikuti oleh sekolah dasar dan tingkat akademik/universitas (Jalil, 2015). Dalam penelitian tersebut peneliti tidak menemukan adanya hubungan yang mengkaitkan tingkat mortalitas dengan tingkat pendidikan terakhir seseorang, namun dapat disimpulkan bahwa semakin rendah tingkat pendidikan seseorang maka resiko terkena pneumonia semakin tinggi, karena kurangnya pengetahuan yang didapat tentang kesehatan.

Berdasarkan tingkat pekerjaan terbanyak adalah pensiunan sebanyak 11 pasien $(37 \%)$, hal ini berbeda dengan hasil penelitian sebelumnya bahwa tingkat pekerjaan terbanyak adalah karyawan swasta sebanyak 33 pasien (34\%). Dalam hasil penelitiannya mengatakan bahwa sosio-ekonomi populasi pasien berada pada tingkatan yang masih rendah, hal tersebut dapat menggambarkan frekuensi yang tinggi terjadinya pneumonia. Hal ini kemungkinan disebabkan karena golongan sosio-ekonomi rendah tidak mampu membayar biaya pengobatan, sehingga dapat memperberat penyakit dan mempercepat kematian (Jalil, 2015).

Tabel 2. Distribusi Frekuensi Penyakit Penyerta $\mathrm{N}=30$

\begin{tabular}{lcc}
\hline Penyakit Penyerta & Frekuensi (f) & Persentase (\%) \\
\hline PPOK & 8 & 26,7 \\
Congestiv Heart Failure (CHF) & 6 & 20,0 \\
Diabetes mellitus & 5 & 16,7 \\
Asma & 5 & 16,7 \\
TB paru & 2 & 6,7 \\
CVD & 2 & 6,7 \\
Sepsis & 1 & 3,3 \\
Bronkitis kronis & 1 & 3,3 \\
Total Pasien & 30 & 100 \\
\hline
\end{tabular}

Keterangan \% : presentase dihitung terhadap jumlah total pasien

Berdasarkan hasil penelitian pada table 2. diagnosa dan penyakit penyerta pada pasien pneumonia yang paling banyak antara lain PPOK sebesar 8 pasien $(26,7 \%)$, penyakit gagal jantung kongestif sebesar $6(20 \%)$, dan diabetes mellitus sebesar 5 pasien (16,7\%), dan asma sebesar 5 pasien (16,7\%). Penelitian ini berbeda dengan penelitian sebelumnya bahwa penyakit penyerta yang terbanyak adalah penyakit jantung kongestif, diabetes mellitus dan penyakit ginjal (Faisal, Burhan, Aniwidyaningsih, \& Kekalih, 2014).

Diar Gustianti lstita"* Puskesmas Labuhan Ratu Bandar Lampung, *Email: diaristita25@gmail.com

Dian Ratih Laksmitawati ${ }^{2}$ Universitas Pancasila. Email: dianratih.ffup@gmail.com

Magdalena Niken ${ }^{3}$ Rumah Sakit Umum Pusat Fatmawati Jakarta. *Email: lenasanjayal@gmail.com 
Evaluasi penggunaan obat dan identifikasi drug related problem (DRP) pada pasien pneumonia di ruang rawat inap rumah sakit umum pusat Fatmawati Jakarta (periode Desember 2014 - Februari 2015)

Tabel 3. Distribusi Frekuensi Penggunaan Obat

\begin{tabular}{lcc}
\hline Kelas Terapi & Frekuensi (f) & Persentase \% \\
& & \\
\hline Antibiotik & 30 & 100 \\
Bronkodilator & 30 & 100 \\
Antitukak lambung & 28 & 93 \\
Anti hipertensi & 23 & 77 \\
Mukolitik & 22 & 73 \\
Kortikosteroid & 21 & 70 \\
Vitamin & 15 & 50 \\
Ekspektoran & 9 & 30 \\
Antipiretik & 8 & 27 \\
Antikoagulan & 7 & 23 \\
Diabetes Melitus & 6 & 20 \\
Obat Kardiotonik & 5 & 17 \\
Anti Lipidemia & 4 & 13 \\
Pencahar & 3 & 10 \\
Obat Syaraf & 3 & 10 \\
Antitusif & 2 & 7 \\
Analgetik Inflamasi Non Steriid & 2 & 7 \\
(AlNS) & & \\
Antipsikotik & 2 & 7 \\
Anti Hiperurisemia & 2 & 3 \\
Anti Fibrinolitik & 1 & 3 \\
\hline
\end{tabular}

Penggunaan obat yang paling sering digunakan pada pasien pneumonia di RSUP Fatmawati periode Desember 2014 - Februari 2015 adalah antibiotik sebesar 30 (100\%), bronkodilator sebesar 30 (100\%), obat tukak lambung sebesar 28 (93\%), anti hipertensi sebesar 23 (77\%) dan mukolitik sebesar 22 (73\%). Hal ini sesuai dengan tatalaksana pedoman pengobatan pneumonia (Perhimpunan Dokter Paru Indonesia, 2003; American Thoracic Society, 2005). Antibiotik merupakan pengobatan utama untuk mengobati penyakit pneumonia yang disebabkan oleh bakteri dan mikroorganisme lainnya. Bronkodilator digunakan sebagai obat pendukung untuk mengobati gejala sesak nafas pada pasien yang menderita pneumonia. Obat ketiga yaitu tukak lambung sering digunakan dalam pengobatan ini dikarenakan pasien yang menderita pneumonia rata-rata tergolong dalam usia lanjut diatas 65 tahun, dimana pasien dengan usia tersebut mengalami keluhan dengan asam lambung.

Diar Gustianti lstita"* Puskesmas Labuhan Ratu Bandar Lampung, *Email: diaristita25@gmail.com

Dian Ratih Laksmitawati ${ }^{2}$ Universitas Pancasila. Email: dianratih.ffup@gmail.com

Magdalena Niken ${ }^{3}$ Rumah Sakit Umum Pusat Fatmawati Jakarta. *Email: lenasanjayal@gmail.com 
Evaluasi penggunaan obat dan identifikasi drug related problem (DRP) pada pasien pneumonia di ruang rawat inap rumah sakit umum pusat Fatmawati Jakarta (periode Desember 2014 - Februari 2015)

Tabel 3. Persentase Angka Kejadian Drug Related Problem (DRP)

\begin{tabular}{|c|c|c|c|}
\hline \multicolumn{2}{|l|}{ Kategori PCNE } & \multirow{2}{*}{$\begin{array}{c}\text { Frekuensi } \\
\text { Kasus (f) }\end{array}$} & \multirow[t]{2}{*}{ Persentase $\%$} \\
\hline Masalah/Problem & Penyebab/Cause & & \\
\hline P1.1Obat tidak efektif & C1.1 Pemilihan obat tidak tepat & 2 & 8 \\
\hline P1.10bat tidak efektif & $\begin{array}{l}\text { C1.2Tidak ada indikasi } \\
\text { penggunaan obat }\end{array}$ & 1 & 4 \\
\hline P1.2 Efek obat tidak optimal & $\begin{array}{l}\text { C3.4 Frekuensi pemberian } \\
\text { kurang }\end{array}$ & 15 & 60 \\
\hline P1.2 Efek obat tidak optimal & C3.1 Dosis kurang & 2 & 8 \\
\hline P1.2 Efek obat tidak optimal & C3.2 Dosis Berlebih & 3 & 12 \\
\hline \multirow[t]{2}{*}{$\begin{array}{l}\text { P1.4 Ada indikasi yang tidak } \\
\text { diterapi }\end{array}$} & $\begin{array}{l}\text { C1.5 Ada indikasi tetapi obat } \\
\text { tidak diberikan }\end{array}$ & 2 & 8 \\
\hline & Jumlah total kasus & 25 & $100 \%$ \\
\hline
\end{tabular}

Hasil analisa DRP berdasarkan formulir PCNE V.6.2 dari tiap pasien dapat dilihat pada lampiran 13 dan 14, data yang diperoleh kemudian disajikan dalam bentuk tabel. Berdasarkan tabel V.13 dan tabel V.14 diperoleh 25 kasus kejadian DRP. Dari 30 pasien ditemukan 18 pasien yang mengalami kejadian DRP dengan total kasus sejumlah 25 , dalam hal ini 1 pasien dapat mengalami lebih dari 1 kasus kejadian DRP. Dalam penelitian ini kasus terbanyak terjadi pada domain (P1.2) yaitu efek obat tidak optimal sebanyak 20 kasus $(80 \%)$ dengan penyebab DRP yang berkaitan dengan pemilihan dosis obat (C.3) meliputi (C3.1) dosis kurang sejumVlah 2 kasus (8\%), (C3.4) frekuensi pemberian kurang sejumlah 15 kasus (60\%), kemudian (C3.2) dosis berlebih sebanyak 3 kasus (12\%).

Kasus yang sering muncul yaitu pada kategori pemilihan dosis yang disebabkan (C3.4) frekuensi pemberian kurang. Terdapat 15 pasien yang mendapatkan ranitidin injeksi dengan dosis $50 \mathrm{mg}$ tiap 12 jam perhari, sedangkan dosis yang tercantum dalam (Drugs Information of Handbooks yaitu $50 \mathrm{mg}$ tiap 6-8 jam perhari. Pertimbangan dokter dalam memberikan dosis ranitidine $2 \times 50 \mathrm{mg} / \mathrm{hari}$ yaitu sebagai terapi profilaksis terhadap penggunaan beberapa obat yang dapat meningkatkan produksi asam lambung seperti kortikosteroid, NSAID, Obat NSAID yang dikombinasi dengan aspirin, dan obat antikoagulan. Ranitidin memiliki waktu paruh eliminasi yang lebih panjang dibandingkan pasien dengan fungsi ginjal yang normal. Lamanya pemberian obat ranitidin secara intravena maupun intramuscular yaitu 4-5 jam dengan waktu paruh eliminasi 2-2,5 jam (Peckham, 2016; Gustafsson, Beermann, \& Abdi, 2013).

Diilihat dari lamanya pemberian obat yang cukup singkat, maka seharusnya pemberian dosis ranitidin untuk pasien dapat dimulai dari $50 \mathrm{mg} / 8 \mathrm{jam}$ dan apabila diperlukan frekuensi pemberian obat dapat dinaikkan menjadi $50 \mathrm{mg} / 6 \mathrm{jam}$ sesuai kondisi klinis masing-masing pasien. Penggunaan dosis obat dibawah dosis standar akan mengakibatkan efek terapi yang diharapkan tidak maksimal atau tidak akan menimbulkan efek terapi. Selain itu, pemberian dosis kurang dapat memperpanjang masa perawatan dan kesembuhan pasien akan lebih lama. (Widyaningrum, \& Nugraheni, 2019).

Kasus DRP selanjutnya pada kategori efek obat tidak optimal (P1.1) yang disebabkan dosis obat kurang (C3.1). Dosis obat kurang dapat diartikan

Diar Gustianti lstital* Puskesmas Labuhan Ratu Bandar Lampung, *Email: diaristita25@gmail.com

Dian Ratih Laksmitawati ${ }^{2}$ Universitas Pancasila. Email: dianratih.ffup@gmail.com

Magdalena Niken ${ }^{3}$ Rumah Sakit Umum Pusat Fatmawati Jakarta. *Email: lenasanjayal@gmail.com 
Evaluasi penggunaan obat dan identifikasi drug related problem (DRP) pada pasien pneumonia di ruang rawat inap rumah sakit umum pusat Fatmawati Jakarta (periode Desember 2014 - Februari 2015)

obat tidak mencapai MEC (minimum efective concentration) sehingga tidak menimbulkan efek terapi, hal ini disebabkan karena dosis terlalu rendah untuk efek yang diinginkan, interval pemakaian obat terlalu panjang, terjadi interaksi yang menyebabkan berkurangnya bioavailabilitas, dan durasi obat terlalu pendek. Kasus lainnya yaitu pada pasien no. 6 dimana terjadi kesalahan dalam pemberian volume sendok, dimana seharusnya obat diberikan dalam takaran sendok makan $(15 \mathrm{ml})$, kasus ini terjadi pada pemberian obat obh dengan dosis 3 kali sehari $5 \mathrm{ml}$, sehingga menyebabkan dosis menjadi berkurang. Terdapat pada kasus pasien no 18, dimana pasien mendapatkan obat spironolakton dengan dosis $1 \times 12,5 \mathrm{mg}$ sedangkan dosis dalam Drugs Information of Handbooks adalah 25-200 mg perhari dalam dosis terbagi, sehingga dosis yang $\mathrm{di}$ berikan menjadi tidak optimal untuk terapi pengobatan pasien. Ketepatan dosis sangat diperlukan dalam keberhasilan terapi, jika dosis atau frekuensi obat kurang dapat menyebabkan terapi yang tidak optimal (Priyanto, 2009).

Pada kasus dengan penyebab DRP yaitu dosis berlebih (C3.2). Kasus DRP terjadi pada pemberian obat sirup yaitu sukralfat pada pasien dengan no. urut $8,11,12$, dimana terjadi kesalahan dalam volume pemberian sendok, yang tertulis dalam formulir pengobatan pasien sukralfat diberikan 3 kali sehari 1 sendok makan (15 ml). Berdasarkan Drug information of handbook dosis yang diberikan seharusnya 4 kali sehari $10 \mathrm{ml}(10 \mathrm{ml}=1$ gram setiap 6 jam) artinya dosis menjadi terla lu tinggi ketika digunakan sendok makan dan frekuensi pemberian obat menjadi kurang. Sukralfat merupakan garam aluminium dari sukrosa oktasulfat, sehingga sejumlah kecil aluminium dapat diabsropsi pada penggunaan sukralfat, oleh karena itu dapat dijadikan perhatian bila sukralfat diberikan pada pasien yang mengalami gagal ginjal, yang beresiko terhadap kelebihan alumunium (DiPiro, Talbert, Yee, Matzke, Wells, \& Posey, 2008).

Terdapat kejadian DRP pada domain (P1.1) yaitu efek obat tidak efektif sebanyak 3 kasus (12\%) yang disebabkan antara lain (C1.1) yaitu pemilihan obat tidak tepat sebanyak 2 kasus dan (C1.2) tidak ada indikasi penggunaan obat sebanyak 1 kasus. Kasus pertama terjadi pada pasien no 11. mendapatkan antibiotik yang tidak sesuai dengan hasil kultur, berdasarkan hasil kultur tanggal 11 Desember 2014 ditemukan adanya bakteri Staphylococcus epidermidis, namun bakteri tersebut sudah mengalami resistensi terhadap antibiotik ceftriaxon+levofloxacin data pada lampiran no.12, tetapi antibiotik tersebut masih diberikan kepada pasien. Pemilihan antibiotik yang tidak tepat dapat berpotensi menyebabkan efek obat menjadi tidak efektif karena tidak dapat membunuh atau menghambat pertumbuhan bakteri. Hal ini dapat dilihat dari hasil pemeriksaan laboratorium saat pasien masuk ke ruang rawat inap, nilai leukosit pasien tidak mengalami penurunan tetapi terjadi peningkatan pada hari ke-11 pasien dirawat. Kemudian dokter mengganti antibiotik tersebut dengan meropenem $3 \times 1 \mathrm{gr}$ iv yang masih sensitif terhadap hasil kultur bakteri tersebut. Kasus kedua terjadi pada pasien dengan no urut 14. Pasien menerima antibiotik yang tidak sesuai dengan hasil kultur, berdasarkan hasil kultur tanggal 22 januari 2015 ditemukan adanya bakteri gram (-) batang dan gram (+) staphylococcus aureus, bakteri tersebut sudah mengalami resistensi terhadap levofloxacin, tetapi antibiotik tersebut masih diberikan kepada pasien. Pada tanggal 24 Januari dengan melihat kondisi pasien dan pertimbangan lainnya, dokter mengganti levofloxacin injeksi dengan antibiotik oral yaitu co-amoxyclav dengan dosis $3 \times 1$ tab. Ketidaksesuain pemilihan antibiotik dengan hasil kultur dapat berpotensi menyebabkan efek obat menjadi tidak efektif, karena antibiotik tersebut tidak dapat membunuh dan menghambat pertumbuhan bakteri (Priyanto, 2009) .

Terdapat 1 kasus pada pasien no. 4, ditemukan DRP pada kategori penyebab (C1.2) tidak ada indikasi penggunaan obat, dimana obat yang diberikan tidak sesuai dengan kondisi pasien. Permasalahan ini terdapat pada penggunaan parasetamol, pada saat pasien masuk ruang rawat inap dalam kondisi demam namun setelah diterapi dengan parasetamol suhu tubuh pasien sudah normal tetapi paracetamol masih diberikan, sedangkan pemberian paracetamol hanya diperlukan saja dan penggunaan jangka waktu yang lama beresiko dapat menyebabkan risiko terjadinya kerusakan hati, karena paracetamol merupakan

Diar Gustianti lstital* Puskesmas Labuhan Ratu Bandar Lampung, *Email: diaristita25@gmail.com

Dian Ratih Laksmitawati ${ }^{2}$ Universitas Pancasila. Email: dianratih.ffup@gmail.com

Magdalena Niken ${ }^{3}$ Rumah Sakit Umum Pusat Fatmawati Jakarta. *Email: lenasanjayal@gmail.com 
Evaluasi penggunaan obat dan identifikasi drug related problem (DRP) pada pasien pneumonia di ruang rawat inap rumah sakit umum pusat Fatmawati Jakarta (periode Desember 2014 - Februari 2015)

salah satu drug induce hepatotoxicity (Katzung, Masters, \& Trevor, 2010).

Terdapat 2 kasus $(8 \%)$ pada domain DRP (P1.4) ada indikasi yang tidak di terapi yang disebabkan (C1.5) ada indikasi tetapi obat tidak diberikan. Kasus pertama pada pasien no. 5 dalam catatan rekam medis pasien memiliki keluhan batuk yang disertai dahak tetapi tidak diberikan obat, dan kasus kedua pada pasien no. 6 berdasarkan hasil kultur bakteri ditemukan adanya jamur namun pasien tidak diberikan obat anti jamur.

\section{SIMPULAN}

Data demografi menunjukkan mayoritas pasien pneumonia berjenis kelamin pria sebanyak 19 pasien (63\%), 17 pasien (57\%) tergolong kelompok usia > 65 tahun, tingkat pendidikan terbanyak adalah tamatan sekolah dasar sebanyak 14 pasien $(47 \%)$, tingkat pekerjaan yang terbanyak adalah pensiunan sebanyak 11 pasien (37\%), jenis penyakit penyerta yang ditemui mayoritas adalah PPOK sebanyak 8 pasien $(26,7 \%)$.

Hasil evaluasi penggunaan obat diketahui bahwa 5 kelas terapi obat terbanyak yang digunakan adalah antibiotik sebanyak 30 pasien (100\%), bronkodilator sebanyak 30 pasien $(100 \%)$, anti tukak lambung sebanyak 28 pasien (93\%), anti hipertensi sebanyak 23 pasien $(77 \%)$ dan mukolitik sebanyak 22 pasien (77\%).

Hasil penelitian menunjukkan bahwa Drug Related Problem (DRP) terdapat 18 pasien mengalami kejadian DRP dari 25 jumlah total kasus, mayoritas kejadian DRP terdapat pada domain (P1.2) yaitu efek obat tidak optimal sejumlah 20 kasus $(80 \%)$ disebabkan antara lain dosis obat kurang (C3.1) sebanyak 2 kasus (8\%), (C3.4) frekuensi pemberian kurang sejumlah 15 kasus (60\%), (C3.2) dosis obat berlebih sebanyak 3 kasus $(12 \%)$, kemudian terdapat 10 kasus interaksi obat yang bersifat potensial.

\section{SARAN}

Untuk mendapatkan hasil penelitian yang lebih baik di penelitian selanjutnya, maka sebaiknya dilakukan pengambilan sampel dengan rentan waktu yang panjang dan dengan jumlah sampel yang lebih besar dengan mengembangkan kriteria inklusi sampelnya.

\section{DAFTAR PUSTAKA}

Ade, T. W. (2018). Evaluasi kualitas penggunaan antibiotik pada pasien pneumonia komunitas di bangsal penyakit dalam RSUP DR. M. Djamil Padang Dengan Metode Gyssens (Doctoral dissertation, Universitas Andalas).

American Thoracic Society, \& Infectious Diseases Society of America. (2005). Guidelines for the management of adults with hospital-acquired, ventilator-associated, and healthcare-associated pneumonia. American journal of respiratory and critical care medicine, 171(4), 388.

Astiti, P. M. A., Mukaddas, A., \& Illah, S. A. (2017). Identifikasi Drug Related Problems (DRPs) Pada Pasien Pediatri Pneumonia Komunitas di Instalasi Rawat Inap RSD Madani Provinsi Sulawesi Tengah. Jurnal Farmasi Galenika (Galenika Journal of Pharmacy), 3(1), 57-63.

Badan Penelitian dan Pengembangan Kesehatan Kementerian Kesehatan Republik Indonesia. (2013). Penyajian Pokok-Pokok Hasil Riset Kesehatan Dasar 2013. Diakses dari: http://kesga.kemkes.go.id/images/pedoman/Data \%20Riskesdas \%202013.pdf

DiPiro, J. T., Talbert, R. L., Yee, G. C., Matzke, G. R., Wells, B. G., \& Posey, L. M. (2014). Pharmacotherapy: A Pathophysiologic Approach, ed. McGraw-Hill Medical, New York.

Faisal, F., Burhan, E., Aniwidyaningsih, W., \& Kekalih, A. (2014). Penilaian respon pengobatan empiris pada pasien rawat inap dengan pneumonia komunitas. Journal respirology, 34, 60-70.

Diar Gustianti lstita"* Puskesmas Labuhan Ratu Bandar Lampung, *Email: diaristita25@gmail.com

Dian Ratih Laksmitawati ${ }^{2}$ Universitas Pancasila. Email: dianratih.ffup@gmail.com

Magdalena Niken ${ }^{3}$ Rumah Sakit Umum Pusat Fatmawati Jakarta. *Email: lenasanjayal@gmail.com 
Evaluasi penggunaan obat dan identifikasi drug related problem (DRP) pada pasien pneumonia di ruang rawat inap rumah sakit umum pusat Fatmawati Jakarta (periode Desember 2014 - Februari 2015)

Gustafsson, L. L., Beermann, B., \& Abdi, Y. A. (2013). Handbook of drugs for tropical parasitic infections. Taylor and Francis Ltd.

Jalil, A. N. A. (2015). Profil Pasien Pneumonia Komunitas di Rumah Sakit Umum Daerah Cengkareng Tahun 2013-2014 (Bachelor's thesis, UIN Syarif HIdayatullah Jakarta: FKIK, 2015).

Kaparang, P. C. (2014). Evaluasi Kerasionalan Penggunaan Antibiotika pada Pengobatan Pneumonia Anak di Instalasi Rawat Inap RSUP Prof. Dr. RD Kandou Manado Periode JanuariDesember 2013. Pharmacon, 3(3).

Katzung, B. G., Masters, S. B., \& Trevor, A. J. (2010). Farmakologi dasar \& klinik. Edisi, 10, 609-612

Lozano, R., Naghavi, M., Foreman, K., Lim, S., Shibuya, K., Aboyans, V., \& AlMazroa, M. A. (2012). Global and regional mortality from 235 causes of death for 20 age groups in 1990 and 2010: a systematic analysis for the Global Burden of Disease Study 2010. The lancet, 380(9859), 20952128.

Mandell, L. A., Wunderink, R. G., Anzueto, A., Bartlett, J. G., Campbell, G. D., Dean, N. C., \& Torres, A. (2007). Infectious Diseases Society of America/American Thoracic Society consensus guidelines on the management of communityacquired pneumonia in adults. Clinical infectious diseases, 44(Supplement_2), S27-S72.

Munarsih, F. C., Natadidjaja, R. I., \& Syamsudin, S. (2018). Pengaruh Pemberian Antibiotik berdasar Panduan terhadap Lama Tinggal pada Pasien Pneumonia Komunitas di Rumah Sakit. Jurnal Penyakit Dalam Indonesia, 5(3), 141-145.
Nugroho, F., Utami, P. I., \& Astuti, I. Y. (2011). Evaluasi penggunaan antibiotik pada penyakit pneumonia di Rumah Sakit Umum Daerah Purbalingga. Pharmacy: Jurnal Farmasi Indonesia (Pharmaceutical Journal of Indonesia), 8(01).

Peckham, C. (2016). Medscape physician compensation report 2016. Web site http://www. medscape.

com/features/slideshow/compensation/2016/public/ overview.

Perhimpunan Dokter Paru Indonesia.(2003).Pneumonia komuniti:pedoman diagnosis\&PenatalaksanaanDi indonesia. Diakses dari https://adoc.tips/queue/pedoman-diagnosispenatalaksanaan-di-indonesia.html

Priyanto, A. D. (2009). Farmakoterapi dan Terminologi Medis. Leskonfi, Jakarta.

Purwanggana, A., Nissa, A., \& Fauziyah, S. (2016). Evaluasi penggunaan antibiotik pada pasien pneumonia komunitas rawat inap di RUMKITAL Dr.Mintohardjo Jakarta Tahun 2015. Diakses dari: http://perpusffup.or.id/index.php?p=show detail\&id= $\underline{8859}$

Sudoyo, A. W., Setiyohadi, B., Alwi, I., Simadibrata, M., \& Setiati, S. (2010). IImu penyakit dalam. Jakarta: Pusat Penerbitan IPD Fakultas Kedokteran Umum Indonesia.

Syukriati, C. (2016). Evaluasi pengelolaan obat pada puskesmas di kota pariaman tahun 20132014 (Doctoral dissertation, Universitas Andalas).

Widyaningrum, B. I., \& Nugraheni, A. Y. (2019). Evaluasi Drug Related Problems (DRPs) Pada Pasien Tukak Peptik di RSUD Dr. Moewardi Tahun 2017 (Doctoral dissertation, Universitas Muhammadiyah Surakarta).

Diar Gustianti lstital* Puskesmas Labuhan Ratu Bandar Lampung, *Email: diaristita25@gmail.com

Dian Ratih Laksmitawati ${ }^{2}$ Universitas Pancasila. Email: dianratih.ffup@gmail.com

Magdalena Niken ${ }^{3}$ Rumah Sakit Umum Pusat Fatmawati Jakarta. *Email: lenasanjayal@gmail.com 